\title{
Brazilian Protocol for Sexually Transmitted infections, 2020: pelvic inflammatory disease
}

\author{
Maria Luiza Bezerra Menezes ${ }^{[1]}$, Paulo Cesar Giraldo[ ${ }^{[2]}$, lara Moreno Linhares ${ }^{[3]}$, \\ Neide Aparecida Tosato Boldrini ${ }^{[4]}$ and Mayra Gonçalves Aragon ${ }^{[5,[6]}$
}

\author{
[1]. Universidade de Pernambuco, Departamento Materno-Infantil, Recife, PE, Brasil. \\ [2]. Universidade Estadual de Campinas, Departamento de Tocoginecologia, Campinas, SP, Brasil. \\ [3]. Universidade de São Paulo, Disciplina de Ginecologia, Departamento de Obstetrícia e Ginecologia, São Paulo, SP, Brasil. \\ [4]. Universidade Federal do Espírito Santo, Departamento de Ginecologia e Obstetrícia, Vitória, ES, Brasil. \\ [5]. Ministério da Saúde, Secretaria de Vigilância em Saúde, Brasilia, DF, Brasil. \\ [6]. Universidade Federal do Espírito Santo, Programa de Pós-Graduação em Doenças Infecciosas, Vitória, ES, Brasil.
}

\begin{abstract}
Pelvic Inflammatory Disease is a topic included in the Clinical Protocol and Therapeutic Guidelines for Comprehensive Care for People with Sexually Transmitted Infections, published by the Brazilian Ministry of Health in 2020. Pelvic inflammatory disease is an upper female genital tract acute infection due to canalicular spread of endogenous cervicovaginal microorganisms and especially the sexually transmitted microorganisms. Standing out among the etiological agents involved are Chlamydia trachomatis and Neisseria gonorrhoeae. The main sequelae are chronic pelvic pain, infertility, and ectopic pregnancy. Clinical diagnosis is the most important practical approach. Antibiotic treatment must start immediately after the clinical suspicion. Guidelines for health service managers and health professionals on diagnostic tests, treatment, follow-up, counseling, notification, handling sexual partners and special populations are described. Given the increased availability of the molecular biology techniques in Brazil, C. trachomatis and N. gonorrhoeae screening are recommended as a disease prevention strategy.
\end{abstract}

Keywords: Pelvic infection. Pelvic pain. Ectopic pregnancy. Infertility. Chlamydia trachomatis. Neisseria gonorrhoeae.

Highlighted excerpt: Pelvic inflammatory disease is one of the most significant sexually transmitted infections, and in most cases, it is a main consequence of cervicitis.

\section{FOREWORD}

This article addresses pelvic inflammatory disease, included in the Clinical Protocol and Therapeutic Guidelines (PCDT) for Comprehensive Care for People with Sexually Transmitted Infections (STI), published by the Health Surveillance Secretariat of the Brazilian Ministry of Health. For the development of the PDCT, selection and analysis of available evidence were performed, followed by discussions with specialists. The PDCT was approved by the National Committee for Technology Incorporation to the Brazilian National Health System (Conitec) ${ }^{1}$ and updated by the panel of specialists in STI in 2020.

\footnotetext{
Corresponding author: Maria Luiza Bezerra Menezes.

e-mail: luiza.menezes.24.09@gmail.com

(D) https://orcid.org/0000-0001-7001-2005

Received 01 February 2021

Accepted 10 March 2021
}

\section{EPIDEMIOLOGY}

Pelvic inflammatory disease is defined as the clinical inflammatory and infectious syndrome arising from the ascent of microorganisms from the lower genital tract (vagina and cervix) to the upper genital tract, which may harm the endometrium, tubes, ovaries, pelvic peritoneum, and adjacent structures. Consequently, endometritis, salpingitis, oophoritis, and pelvic peritonitis can arise, depending on the infection's extent. Dissemination occurs predominantly through the canalicular route ${ }^{2,3}$.

Although the classical pelvic inflammatory disease definition includes only canalicular and spontaneous microorganism dissemination, not associated with surgical or procedures or pregnancy $^{3}$, intrauterine devices (IUD) insertion, endometrium biopsy, curettage, among others, are also currently considered as responsible for the syndrome ${ }^{2}$.

Pelvic inflammatory disease is one of the most significant sexually transmitted infections, and a principal negative consequence of cervicitis. It is estimated that there is one case of pelvic inflammatory disease for every eight to ten women with Chlamydia trachomatis cervicitis ${ }^{3}$. The absence of rapid diagnosis 
and treatment or inadequate treatment increases the risk of severe complications, with negative consequences for women's health, as well as economic and social costs. Most sequelae involve infertility, ectopic pregnancy, and chronic pelvic pain ${ }^{4-6}$. It has been reported that, after seven years from the first episode, $21.3 \%$ of women presented recurrence, $19 \%$ developed infertility, and 42.7\% experienced chronic pelvic pain 7 .

Existing prevalence data are underestimated, since pelvic inflammatory disease is not compulsorily notified, and, for this reason, the number of affected women is unknown ${ }^{8}$. Also, many cases present mild or few clinical symptoms which are not noticed. Studies indicate that $10 \%$ to $40 \%$ of women with cervicitis caused by $N$. gonorrhoeae or $C$. trachomatis develop the pelvic inflammatory disease ${ }^{9,10}$. In Brazil, the true prevalence of the disease is unknown. Using Brazilian National Health System Hospital Information System, the hospitalization number of women with pelvic inflammatory disease from January 2005 to August 2006 was obtained. The hospitalization average per year was 45,343 cases. However, it is essential to highlight that such data reflects only severe cases of the syndrome, those that required hospital care, and they represent only a small fraction of the affected women since in most of them the infection elicits only light or moderate symptoms or is asymptomatic ${ }^{11}$.

In a study conducted in the United States, $4.4 \%$ of 1,171 sexually active women between 18 and 44 years old had symptoms suggesting pelvic inflammatory disease ${ }^{12}$. From this result, it was estimated that for the period 2013-2014, 2.5 million women had pelvic inflammatory disease in the United States ${ }^{13}$. Another study suggests that 800,000 cases of the disease occur per year in that country ${ }^{14}$. Sutton et al. (2005) estimated 1.2 million medical visits yearly due to pelvic inflammatory disease in developed countries ${ }^{15}$.

The endocervix is classically considered a protecting barrier in the upper genital tract. Endocervical infection with sexually transmitted pathogens breaks this barrier providing access of vaginal bacteria to the upper genital organs, infecting endometrium, endosalpinx, pelvic peritoneum, and subjacent stroma ${ }^{2,3,16}$.
The reasons for which bacteria in the lower genital tract cause pelvic inflammatory disease in only some women are not entirely known. Still, they may be associated with genetic variations, retrograde menstruation, immune response, bacterial load and menstrual cycle hormonal oscillations, considering that the menstrual cervix mucous is less bacteriostatic ${ }^{17-19}$. The infection's progression by anaerobic agents determines a higher oxygen consumption and a local oxyreduction potential decrease, which, alongside tissue devitalization, provides an environment of microaerophilia or even anaerobiosis (Monif theory) ${ }^{16}$. In such environment, the microorganisms that reached the upper genital tract start a slow-growing phase, and opportunistic anaerobic agents develop. The result is a polymicrobial infectious condition ${ }^{2,3,16}$.

From the observation that two-thirds of women with STI did not have any previous history of treatment for pelvic inflammatory disease, the concept of subclinical pelvic inflammatory disease was proposed, being as common as the clinical disease, and presenting the same etiology ${ }^{6,20}$.

Most cases arise from sexually transmitted pathogenic agents, such as $N$. gonorrhoeae and C. trachomatis ${ }^{7,21,22}$. A minor fraction of acute disease is not sexually transmitted but associated with germs that colonize the lower genital tract or enteric ones such as Mycoplasma hominis, Ureaplasma urealyticum, Peptococcus spp., Peptoestreptococcus spp., Bacteroides spp., Escherichia coli, Streptococcus agalactiae, and Campylobacter spp., in addition to respiratory pathogens (for example, Haemophilus influenzae, Streptococcus pneumoniae, Group A streptococci and Staphylococcus aureus ${ }^{23-27}$. Facultative aerobic organisms in the microbiota are deemed potentially causing agents ${ }^{27}$. Etiological agents of pelvic inflammatory disease are listed in Figure 1.

The use of culture methods for microorganisms identification made it possible to understand better the composition of the healthy vaginal microbiota, in mostly women comprised of one or more species of Lactobacillus, which act to protect the vaginal environment ${ }^{28}$. Unbalanced status, such as bacterial vaginosis, which comprises a reduction or lack of Lactobacillus sp., and increase in

\begin{tabular}{|l|l|}
\hline Microorganism origin & Etiological agents \\
\hline Sexually transmitted microorganisms & $\begin{array}{l}\text { Chlamydia trachomatis } \\
\text { Neisseria gonorrhoeae } \\
\text { Mycoplasma genitalium } \\
\text { Trichomonas vaginalis }\end{array}$ \\
\hline Non-sexually transmitted microorganisms & $\begin{array}{l}\text { Mycoplasma hominis } \\
\text { Ureaplasma urealyticum }\end{array}$ \\
\hline & $\begin{array}{l}\text { Bacteroides spp. e fragilis } \\
\text { Peptoestreptococcus spp. } \\
\text { Prevotella spp. }\end{array}$ \\
\hline & $\begin{array}{l}\text { Escherichia coli } \\
\text { Gardnerella vaginalis } \\
\text { Haemophilus influenzae } \\
\text { Streptococcus spp. e agalactieae } \\
\text { Atopobium vaginae }\end{array}$ \\
\hline
\end{tabular}

Source: adapted from Clinical Protocol and Treatment Guidelines for Comprehensive Care for People with Sexually Transmitted Infections, $2020^{34}$.

FIGURE 1: Etiological agents of pelvic inflammatory disease. 
concentrations and variability of anaerobic microorganisms such as Gardnerella vaginalis and Mycoplasma sp., can contribute to the migration of microorganisms to the upper genital tract. It was already shown that bacterial vaginosis doubles the risk of pelvic inflammatory disease ${ }^{18,29,30}$.

The microorganism insulation in the upper genital tract has been associated with disease stages. However, studies using molecular methods have shown microorganisms in healthy women's endometrium, including Lactobacillus species, Mycoplasma hominins, G. vaginalis, and Enterobacter sp., among others ${ }^{31,32}$. However, although healthy women can host such microorganisms, their role in health and disease stages is still unknown. The interactions between the infectious agent and genital tract immunity are probably determinant for the permanence in the health or changes to a disease stage. In addition, molecular techniques have identified new microorganisms, such as Atopobium vaginae. Studies have also identified new bacteria species and genera in the upper genital tract of women with pelvic inflammatory disease. Therefore, questions about the presence of a healthy microbiota in the upper genital tract and the possibility of mechanisms predisposing to physiologic vaginal flora unbalance that also predispose to infection need to be clarified. Such answers will undoubtedly lead to investigations on the best approach for diagnosis and treatment of pelvic inflammatory disease, as well as most efficient ways to prevent it ${ }^{33}$.

Risk factors for pelvic inflammatory disease include: ${ }^{34}$ 1) age group, as adolescents with multiple sexual partners, due to biological and behavioral factors characteristic in this phase, present risks three times greater for the development of acute pelvic inflammatory disease in comparison with women older than 25 years of age ${ }^{35,36}$, regardless of education level and family income; 2) sexual behavior with multiple partners, early start of sexual activities and new partners ${ }^{35} ; 3$ ) using IUD, as women using such device present a slightly higher risk of pelvic inflammatory disease in the first 20 days of insertion, regardless of the type of IUD inserted - copper or levonorgestrel release ${ }^{37}$. This risk is reduced in women treated for STI before IUD insertion ${ }^{38}$.

\section{CLINICAL ASPECTS}

Clinical diagnosis is still the principal approach to pelvic inflammatory disease, despite the wide specter of clinical presentations. Around $65 \%$ of the cases can be oligosymptomatic and asymptomatic and later present infertility caused by tubal factors ${ }^{39}$. The time course is usually acute, developing for several days. However, a more extensive manifestation can take place, from weeks to months. The typical disease symptoms are fever, abdominal pain, pelvic pain, dyspareunia, vaginal discharge, and dysuria or frequent urination ${ }^{39,40}$. Abnormal uterine bleeding (post-intercourse bleeding, intermenstrual bleeding, and menorrhagia) in one-third or more of the cases is observed. Recent abdominal or pelvic pain, or both, intensifying during intercourse or vigorous movement, can be the only symptom. Pain starting during or right after menstruation is particularly suggestive ${ }^{41}$. Only a minority develop peritonitis or pelvic abscess, which generally manifest through intense pain, higher sensitivity to the examination, and systemic characteristics, such as fever ${ }^{41-43}$. More rarely, an extension up to the liver capsule, causing perihepatitis (Fitz-Hugh Curtis syndrome) or sepsis, or both can occur ${ }^{27,44}$.
The clinical examination must include vital sign assessment; abdominal examination; vaginal speculum examination, with cervical inspection for friability (easy bleeding) and cervical mucopurulent discharge; bimanual vaginal examination, with cervical mobilization; and adnexal palpation (ovaries and uterine tube) $)^{42}$.

The sequelae are chronic pelvic pain, ectopic pregnancy, and infertility. Around $25 \%$ of the women with pelvic inflammatory disease will present chronic pelvic pain, $10 \%$ to $50 \%$ will be infertile, and $15 \%$ to $60 \%$ will have an ectopic pelvic inflammatory illness, generally caused by scars and adherence in the fallopian tubes ${ }^{7,45,46}$. Such proportions increase typically with the number of infections, being very high in parts of Africa, Asia, and South America, where healthcare services are not easily accessible ${ }^{47,48}$. There are also reports on pelvic inflammatory disease associated with a higher risk of cerebrovascular accident, ovary cancer, and acute small bowel obstruction ${ }^{47-50}$.

\section{DIAGNOSIS}

Clinical diagnosis for pelvic inflammatory disease suspicion is conducted upon three major criteria associated with one minor criterion or one developed criterion ${ }^{34}$, presented in Figure 2.

Laboratory and image examinations help in diagnosis and severity assessment and are central in oligosymptomatic cases. However, in case of high clinical suspicion, treatment must not be delayed.

The following laboratory tests are recommended: complete blood count; erythrocyte sedimentation rate; C-reactive protein; bacterioscopic examination for bacterial vaginosis; endocervical swab culture with antibiogram; molecular biology for $N$. gonorrhoeae and C. trachomatis in material from the endocervix, urethra, laparoscopy, or culdocentesis; qualitative urine examination and urine culture, for dismissing urinary tract infection; hemoculture; pregnancy test, for rejecting the diagnosis of ectopic pregnancy; and imaging exams ${ }^{51}$. Serological exams for C. trachomatis are not recommended for pelvic inflammatory disease diagnosis.

Pelvic ultrasound is the preferential imaging exam, as it is accessible and noninvasive, mainly for evaluating possible associated complications, such as tubo-ovarian abscesses, and for excluding differential diagnosis ${ }^{52}$. In pelvic inflammatory disease, the main suspicious sonographic finding is a thin layer of liquid filling the tubes, with or without free fluid in the pelvis. Tomography and resonance examinations can help in differential diagnosis of peritonitis ${ }^{42,51}$.

Laparoscopy represents an accurate salpingitis diagnosis resource, enabling a complete bacteriologic diagnosis. However, it does not detect endometritis and less intense tube inflammation, and, thus, its daily use is not justifiable in the disease's initial phase, considering low sensitivity ${ }^{18,19}$ and associated morbidity ${ }^{41-43}$. Laparoscopy had its great merit in the 1980 s, as it led to the Gainesville clinical classification ${ }^{53}$; in practice, it still very used according to clinical and ultrasound findings, being necessary for treatment guidance, to wit: stage I - salpingitis without peritonitis; stage II - salpingitis with peritonitis; stage III - the presence of tuboovarian complex, divided in A (hydrosalpinx) and B (tubo-ovarian abscess); stage IV - ruptured tubo-ovarian abscess; and stage $\mathrm{V}$ - any of above, associated to genital tuberculosis. 


\begin{tabular}{|l|l|}
\hline Criteria & Description \\
\hline Major criteria & $\begin{array}{l}\text { Hypogastric pain } \\
\text { Pain to adnexal palpation } \\
\text { Pain to cervical movement }\end{array}$ \\
\hline \multirow{2}{*}{ Minor criteria } & $\begin{array}{l}\text { Axillary temperature }>37.5^{\circ} \mathrm{C} \text { or rectal temperature }>38.3^{\circ} \mathrm{C} \\
\text { Vaginal content or abnormal endocervical secretion } \\
\text { Pelvic mass } \\
\text { More than ten white blood cells per immersion field in endocervical material } \\
\text { Leukocytosis in peripheral blood } \\
\text { C-reactive protein or high erythrocyte sedimentation rate } \\
\text { Laboratory proof of gonococcal, chlamydia, or mycoplasma cervical infection }\end{array}$ \\
\hline Developed criteria & $\begin{array}{l}\text { Endometritis histopathologic evidence } \\
\text { Presence of tubo-ovarian or pouch of Douglas abscess in the imaging study } \\
\text { Laparoscopy with pelvic inflammatory disease evidence }\end{array}$ \\
\hline
\end{tabular}

Source: adapted from Clinical Protocol and Treatment Guidelines for Comprehensive Care for People with Sexually Transmitted Infections, $2020^{34}$.

FIGURE 2: Pelvic inflammatory disease diagnosis criteria.

In differential diagnosis, the list includes ectopic pregnancy, acute appendicitis, diverticulitis, urinary tract infection, ureteral lithiasis, ovarian cyst or uterine myoma torsion, ovarian cyst rupture, endometriosis, and ruptured endometrioma, among others ${ }^{2,16,22}$.

\section{TREATMENT}

Figure 3 presents guidance for pelvic inflammatory disease outpatient clinical management and indicates the need for urgency evaluation or hospital treatment ${ }^{34}$.

Treatment must start immediately, aiming at avoiding late complications, such as infertility, ectopic pregnancy, and chronic pelvic pain ${ }^{54}$. Treatment of other common pelvic pain causes (ectopic pregnancy, acute appendicitis, ovarian cyst, and functional pain) is unlikely to be harmed by antimicrobial therapy for pelvic inflammatory disease ${ }^{42}$. In addition to antibiotics, analgesic and antiinflammatory drugs can be used for decreasing symptomatology.

Outpatient treatment applies to women that present light clinical pictures without signs of pelvic peritonitis (Gainesville Stage I) ${ }^{53}$. Other clinical stages and criteria summarized in Figure 4 require hospital treatment ${ }^{34}$.

Therapeutic schemes must present antimicrobial coverage for pelvic inflammatory disease etiological agents ${ }^{34}$ as shown in Figure 5. The antibiotic therapy must have a broad scope, be efficient against $N$. gonorrhoeae, $C$. trachomatis, and anaerobic organisms, especially Bacteroides fragilis, even if they are not confirmed in laboratory examination, and include bacterial vaginosis, Gramnegative bacteria, facultative bacteria, and streptococci ${ }^{55,56}$.

Among the broad-spectrum antibiotics with activity directed for such agents, beta-lactams, aminoglycosides, tetracyclines, lincosamides, and macrolides have been widely studied. They must be used in association with each other and can be administered through parenteral or oral route ${ }^{42,43}$. Parenteral use may be suspended 24 hours after the end of the symptoms, and antimicrobial therapy through oral or intramuscular route must be extended up to 14 days.

In most studies, doxycycline is the antibiotic of choice for treating C. trachomatis. The combination of clindamycin and gentamicin presents moderate activity against $N$. gonorrhoeae and $C$. trachomatis in vitro, and second-generation cephalosporins (cefoxitin or cefotetan) associated with doxycycline shows excellent in vitro results. The ampicillin/sulbactam association is also a good choice $^{55,56}$. Due to a high level of bacterial resistance, quinolones are not used for treating $N$. gonorrhoeae in Brazil ${ }^{57}$.

For pelvic inflammatory disease treatment, PCDT indicates $500 \mathrm{mg}$ of ceftriaxone dosage in the recommended therapeutic schemes $^{34}$. This dosage was chosen in a decision by Conitec, based on a cost-benefit and financial impact evaluation of using ceftriaxone $250 \mathrm{mg}$ in the national territory ${ }^{58}$. International protocols recommend ceftriaxone dosage as $250 \mathrm{mg}$, depending on the availability of the medication and $N$. gonorrhoeae antimicrobial susceptibility local evidences ${ }^{42}$.

Clinical improvement is likely to occur within up to three days from the start of the antimicrobial treatment. The cure is based on the end of signs and symptoms and normalization of inflammatory markers in laboratory tests. A study showed that if the evaluation is carried out with bacteriologic criteria after thirty days, there is still one or more bacterial agents in $40 \%$ of women ${ }^{7}$. If the clinical picture persists or worsens, a diagnostic revision must be considered. Laparoscopy, resonance, or tomography examinations can be conducted in such cases ${ }^{42,51}$. Laparotomy is recommended in cases of adnexal masses unresponsive to treatment or rupturing. Culdotomy may be recommended if the abscess covers the bottom of the pouch of Douglas. In particular instances, tubo-ovarian abscesses can be drained with puncture guided through ultrasound ${ }^{34}$.

A return medical appointment to the outpatient follow-up must be scheduled in the first week, suggesting a second appointment 30 days after hospital discharge. In reproductive planning, the use or removal of hormonal contraceptives and IUD should be evaluate $\mathrm{d}^{34,59}$. We recommend sexual abstinence for 30 days and condoms usage during intercourse after this time period. IUD removal must not be necessarily conducted in light and moderate cases of pelvic inflammatory disease ${ }^{41-43}$. Still, it must be considered 


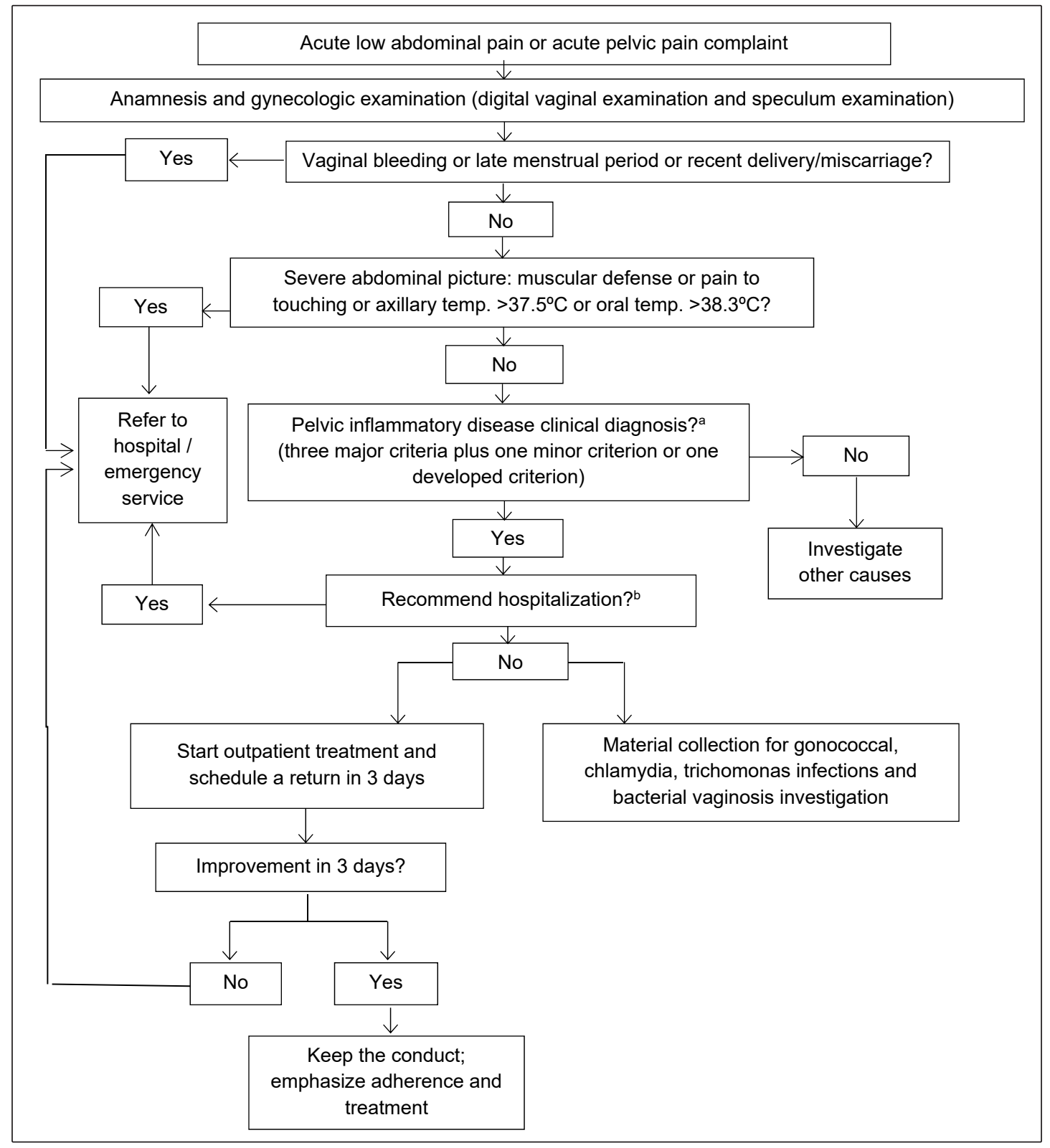

Source: adapted from Clinical Protocol and Treatment Guidelines for Comprehensive Care for People with Sexually Transmitted Infections, $2020^{34}$.

Notes: a) Refer to Figure 2 - Pelvic inflammatory disease diagnosis criteria; b) Refer to Figure 4 - Criteria for recommending pelvic inflammatory disease hospital treatment.

FIGURE 3: Flowchart for pelvic inflammatory disease clinical management.

\section{Criteria for recommending pelvic inflammatory disease hospital treatment}

Tubo-ovarian abscess

Pregnancy

Lack of clinical response after 72 hours from the start of oral antibiotic treatment

Intolerance to oral antibiotics or difficulty in outpatient treatment

Severe general situation, with nausea, vomit, and fever

Difficulty in excluding surgical emergency (ex.: appendicitis, ectopic pregnancy)

Source: adapted from Clinical Protocol and Treatment Guidelines for Comprehensive Care for People with Sexually Transmitted Infections,202034.

FIGURE 4: Criteria for recommending pelvic inflammatory disease hospital treatment. 


\begin{tabular}{|c|c|c|c|}
\hline Treatment & First option & Second option & Third option \\
\hline Outpatient & $\begin{array}{l}\text { Ceftriaxone } 500 \mathrm{mg} \text {, intramuscular (IM), } \\
\text { single dose plus Doxycycline } 100 \mathrm{mg}, 1 \\
\text { pill, per os (PO), twice/day, for } 14 \text { days } \\
\text { plus Metronidazole } 250 \mathrm{mg}, 2 \text { pills, PO, } \\
\text { twice/day, for } 14 \text { days }\end{array}$ & $\begin{array}{l}\text { Cefotaxime } 500 \mathrm{mg}, \text { IM, single dose } \\
\text { plus Doxycycline } 100 \mathrm{mg}, 1 \text { pill, } \\
\mathrm{PO} \text {, twice/day, for } 14 \text { days plus } \\
\text { Metronidazole } 250 \mathrm{mg} \text {, two pills, PO, } \\
\text { twice/day, for } 14 \text { days }\end{array}$ & - \\
\hline Hospital $^{c}$ & $\begin{array}{l}\text { Ceftriaxone } 1 \mathrm{~g} \text {, intravenous } \\
\text { (IV), once/day, for } 14 \text { days plus } \\
\text { Doxycycline } 100 \mathrm{mg}, 1 \text { pill, PO, twice/ } \\
\text { day, for } 14 \text { days plus Metronidazole } \\
400 \mathrm{mg}, \mathrm{IV} \text {, each } 12 \text { hours }\end{array}$ & $\begin{array}{l}\text { Clindamycin } 900 \mathrm{mg} \text {, IV, three times/ } \\
\text { day, for } 14 \text { days plus Gentamicin } \\
\text { (IV or IM): } 3-5 \mathrm{mg} / \mathrm{kg} \text {, once/day for } \\
14 \text { days }\end{array}$ & $\begin{array}{l}\text { Ampicillin/sulbactam } 3 \mathrm{~g}, \text { IV, each } 6 \\
\text { hours, for } 14 \text { days plus Doxycycline } \\
100 \mathrm{mg}, \text { one pill, PO, twice/day, for } \\
14 \text { days }\end{array}$ \\
\hline
\end{tabular}

Source: adapted from Clinical Protocol and Treatment Guidelines for Comprehensive Care for People with Sexually Transmitted Infections,2020 ${ }^{34}$.

Notes: a) Doxycycline is a contraindication during pregnancy; b) According to professional evaluation, metronidazole may be stopped or not prescribed in light and moderate cases due to intolerance to use and the less important role of antibiotic therapy for anaerobic organisms in non-severe cases. Give information on not using alcoholic beverages during and after 24 hours of using metronidazole to avoid the disulfiram-like (Antabuse) effect; c) Parenteral use may be suspended 24 hours after the end of symptoms, and antimicrobial therapy must be extended to 14 days through the oral route; d) Gentamicin may be divided 2 to 3 times/day or reduced dose when clinically recommended.

FIGURE 5: Pelvic inflammatory disease treatment.

if the user wishes to do it or if there is no clinical improvement after 72 hours from the antibiotic therapy or in cases of severe pelvic inflammatory disease ${ }^{38}$. However, when indicated, removal must only take place after two doses of the therapeutic scheme ${ }^{60}$. In such cases, using barrier or hormonal contraceptive methods must be recommended.

The acute episode of pelvic inflammatory disease and its sequela results in high financial costs for women and the health system. Such expenses have increased substantially, considering many women will need assisted reproductive techniques ${ }^{61}$.

\section{SURVEILLANCE, PREVENTION, AND CONTROL}

Like other STIs, pelvic inflammatory disease prevention and control must include counseling focused on the person and their sexual partners. The aim is self-recognition and minimizing risk factors for STI and new pelvic inflammatory disease episodes ${ }^{62}$. HIV, syphilis, and hepatitis B and C testing are recommended. In specific cases, vaccines for hepatitis A, hepatitis B, and HPV must be offered ${ }^{34}$.

All sexual partners must be counseled and evaluated, offering testing and vaccination. Sexual partners of up to two months before the diagnosis must be empirically treated for $N$. gonorrhoeae and $C$. trachomatis with intramuscular ceftriaxone 500mg and azithromycin $1 \mathrm{~g}$ through oral route in a single dose $^{34}$.

Pelvic inflammatory disease is not present in the Ministry of Health compulsory notification diseases, nor are the infections by $N$. gonorrhoeae, C. trachomatis, and Mycoplasma genitalium reported $^{63}$. Despite this, the notifications can be carried out by the Federal District, states, and municipalities, depending on local decisions.

Pelvic inflammatory disease is a substantial public health problem. Mass screening for $N$. gonorrhoeae and C. trachomatis showed a reduction of pelvic inflammatory disease in women. The Center for Disease Control and Prevention of the United States recommends annual screening, primarily for sexually active women younger than 25 years and women older than 25 years with $C$. trachomatis infection risk, including their respective sexual partners. They also consider the possibility of screening men in scenarios with high prevalence and resources ${ }^{42,64}$. In the Brazilian setting, screening N. gonorrhoeae and C. trachomatis is recommended in some situations: first prenatal care medical appointments of pregnant women aged 30 or less, people with STI diagnosis, people living with HIV, sexual violence situations, people using HIV pre-exposure (PrEP) and post-exposure (PEP) prophylaxis and people with receptive anal sexual practice without condom use ${ }^{34}$.

A possibility to be assessed in future protocols is the inclusion of $M$. genitalium diagnosis for women with pelvic inflammatory disease, in addition to $N$. gonorrhoeae and C. trachomatis ${ }^{65}$. European and North-American clinical guidelines included such investigation in women with pelvic inflammatory disease and men with non-gonococcal urethritides. Different studies showed M. genitalium association with cervicitis and pelvic inflammatory disease; however, there is no evidence of benefits for universal screening ${ }^{41-43}$.

\section{SPECIAL POPULATIONS}

Pregnant women with pelvic inflammatory disease have a high risk of miscarriage, chorioamnionitis, and premature delivery ${ }^{42}$, and they must be hospitalized and undergo intravenous broad-spectrum antibiotic treatment immediately. Doxycycline and quinolones are a contraindication during pregnancy ${ }^{34}$.

Despite having a higher risk of pelvic inflammatory disease and complications, children, prepubertal adolescents, and women living with HIV have a similar clinical presentation and must be conducted in the same way as the general population ${ }^{59,66,67}$.

\section{ACKNOWLEDGMENTS}

The authors acknowledge this work's contribution by the members of the technical panel of specialists responsible for developing the 2020 PCDT for Comprehensive Care for People with STI. 


\section{ORCID}

Maria Luiza Bezerra Menezes - 0000-0000-0001-7001-2005

Paulo Cesar Giraldo - 0000-0003-4365-9879

Iara Moreno Linhares - 0000-0002-7846-6885

Neide Aparecida Tosato Boldrini - 0000-0003-1140-5057

Mayra Gonçalves Aragon - 0000-0001-6631-1790

\section{AUTHORS' CONTRIBUTIONS}

Menezes MLB, Giraldo PC, Linhares IM, Boldrini NAT, and Aragon MG contributed equally with the concept, design, drafting, and critical reviewing of the manuscript. All authors approved the final version of the article and are responsible for all its aspects, including the assurance of its accuracy and integrity.

\section{REFERENCES}

1. Brasil. Ministério da Saúde. Portaria MS/SCTIE n $n^{\circ} 42$, de 5 de outubro de 2018. Torna pública a decisão de aprovar o Protocolo Clínico e Diretrizes Terapêuticas para Atenção Integral às Pessoas com Infecções Sexualmente Transmissíveis (IST), no âmbito do Sistema Único de Saúde - SUS [Internet]. Diário Oficial da União, Brasília (DF), 2018 Oct 8 [cited 2020 Oct 2];Seção 1:88. Available from: http://bvsms.saude.gov. br/bvs/saudelegis/sctie/2018/prt0042_08_10_2018.html

2. Ford GW, Decker CF. Pelvic inflammatory disease. Dis Mon [Internet]. 2016 Aug [cited 2020 Oct 2];62(8):301-5. Available from: https://doi. org/10.1016/j.disamonth.2016.03.015

3. Paavonen J. Pelvic Inflammatory disease. From diagnosis to prevention. Dermatol Clin [Internet]. 1998 Oct [cited 2020 Oct 2];16(4):747-56. Available from: https://doi.org/10.1016/s0733-8635(05)70041-3

4. Haggerty CL, Gottlieb SM, Taylor BD, Low N, XU F, Ness RB. Risk of sequelae after Chlamydia trachomatis genital infection in women. $\mathrm{J}$ Infect Dis [Internet]. 2010 Jun [cited 2020 Oct 2];201(Suppl 2):S134-55. Available from: https://doi.org/10.1086/652395

5. World Bank. World development report 1993: investing in health, world development indicators [Internet]. New York: Oxford University Press; 1993 [cited $2020 \mathrm{Jul}$ 20]. Available from: https://openknowledge. worldbank.org/handle/10986/5976

6. Crossman SH. The challenge of pelvic inflammatory disease. Am Fam Physician [Internet]. 2006 Mar [cited 2020 Oct 2];73(5):859-64. [update: Am Fam Physician. 2006 Dec 15;74(12):2024]. Available from: https://www.aafp.org/afp/2006/0301/p859.html

7. Trent M, Bass D, Ness RB, Haggerty C. Recurrent PID, subsequent STI, and reproductive health outcomes: findings from the PID evaluation and clinical health (PEACH Study). Sex Transm Dis [Internet]. 2011 Sep [cited 2020 Oct 2];38(9):879-81. Available from: https://dx.doi.org/10.10 97\%2FOLQ.0b013e31821f918c

8. French CE, Hughes G, Nicholson A, Yung M, Ross JD, Williams T, et al. Estimation of pelvic inflammatory disease diagnoses: trends in England, 2000-2008. Sex Transm Dis [Internet]. 2011 Mar [cited 2020 Oct 2];38(3):158-62. Available from: https://doi.org/10.1097/ olq. $0 \mathrm{~b} 013 \mathrm{e} 3181 \mathrm{f} 22 \mathrm{f} 3 \mathrm{e}$

9. Bakken IJ, Ghaderi S. Incidence of pelvic inflammatory disease in a large cohort of women tested for Chlamydia trachomatis: a historical follow-up study. BMC Infect Dis [Internet]. 2009 Aug [cited 2020 Oct 2];9:130. Available from: https://doi.org/10.1186/1471-2334-9-130

10. Land JA, Van Bergen JEAM, Morré SA, Postma MJ. Epidemiology of Chlamydia trachomatis infection in women and the cost-effectiveness of screening. Hum Reprod Update [Internet]. 2010 Mar-Apr [cited 2020 Oct 2];16(2):189-204. Available from: https://doi.org/10.1093/humupd/ dmp035

11. Pinto VM, Szwarcwald CL, Baroni C, Stringati LL, Inocencio LA, Miranda AE. Chlamydia trachomatis prevalence and risk behaviors in parturient women aged 15 to 24 in Brazil. Sex Transm Dis [Internet]. 2011 Oct [cited 2020 Oct 2];38(10):957-61. Available from: https://doi. org/10.1097/olq.0b013e31822037fc

12. National Center for Health Statics. National health and nutrition examination survey 2013-2014 [Internet]. Washington, D.C.: Centers for Disease Control and Prevention; 2020 [cited 2020 Jul 22]. Available from: https://www.cdc.gov/nchs/nhanes/index.htm

13. Kreisel K, Torrone E, Bernstein K, Hong J, Gorwitz R. Prevalence of pelvic inflammatory disease in sexually experienced women of reproductive age -United States, 2013-2014. MMWR Morb Mortal Wkly Rep [Internet]. 2017 Jan [cited 2020 Oct 2];66(3):80-3. Available from: http://dx.doi.org/10.15585/mmwr.mm6603a3

14. Das Breanne B, Ronda J, Trent M. Pelvic inflammatory disease: improving awareness, prevention, and treatment. Infect Drug Resist [Internet]. 2016 Aug [cited 2020 Oct 2];9:191-7. Available from: https:// dx.doi.org/10.2147\%2FIDR.S91260

15. Sutton MY, Stemberg M, Zaidi A, St Louis ME, Markowitz LE. Trends in pelvic inflammatory disease hospital discharges and ambulatory visits, Unites States, 1885-2001. Sex Transm Dis [Internet]. 2005 Dec [cited 2020 Oct 2];32(12):778-84. Available from: https://doi.org/10.1097/01. olq.0000175375.60973.cb

16. Carvalho NS, Takimura M, Von Lisigen R, Freitas B. Doença inflamatória pélvica. In: Fernandes CE, Sá MF. Tratado de ginecologia FEBRASGO. Rio de Janeiro: Elsevier; 2019. p. 287-96.

17. Korn AP, Hessol NA, Padian NS, Bolan GA, Donegan E, Landers DV, et al. Risk factors for plasma cell endometritis among women with cervical Neisseria gonorrhoeae, cervical Chlamydia trachomatis, or bacterial vaginosis. Am J Obstet Gynecol [Internet]. 1998 May [cited 2020 Oct 2];178(5):987-90. Available from: https://doi.org/10.1016/s0002-9378(98)70536-8

18. Ness RB, Kip KE, Hillier SL, Soper DE, Stamm CA, Sweet RL, et al. A cluster analysis of bacterial vaginosis associated microflora and pelvic inflammatory disease. Am J Epidemiol [Internet]. 2005 Sep [cited 2020 Oct 2];162(6):585-90. Available from: https://doi.org/10.1093/aje/kwi243

19. Morré SA, Karimi O, Ouburg S. Chlamydia trachomatis: identification of susceptibility markers for ocular and sexually transmitted infection by immunogenetics. FEMS Immunol Med Microbiol [Internet]. 2009 Mar [cited 2020 Oct 2];55(2):140-53. Available from: https://doi. org/10.1111/j.1574-695x.2009.00536.x

20. Wiesenfeld HC. Pelvic inflammatory disease: treatment in adults and adolescents [Internet]. [S.1.]: UpToDate; 2019 [cited $2020 \mathrm{Jul}$ 22]. Available from: https://www.uptodate.com/contents/pelvicinflammatory-disease-treatment-in-adults-and-adolescents

21. Short VL, Totten PA, Ness RB, Astete SG, Kelsey SF, Haggerty CL. Clinical presentation of Mycoplasma genitalium infection versus Neisseria gonorrhoeae infection among women with pelvic inflammatory disease. Clin Infect Dis [Internet]. 2009 Jan [cited 2020 Oct 2];48(1):41-7. Available from: https://doi.org/10.1086/594123

22. Sweet RL. Pelvic inflammatory disease: current concepts of diagnosis and management. Curr Infect Dis Rep [Internet]. 2012 Feb [cited 2020 Oct 2]. Available from: https://doi.org/10.1007/s11908-012-0243-y

23. Workowski KA, Berman S; Centers for Disease Control and Prevention (CDC). Sexually transmitted diseases treatment guidelines, 2010. MMWR Recomm Rep [Internet]. 2010 Dec [cited 2020 Oct 2];59(RR12):1-110. Available from: https://www.cdc.gov/mmwr/preview/ mmwrhtml/rr5912a1.htm?s 
24. Haggerty CL, Taylor BD. Mycoplasma genitalium: an emerging cause of pelvic inflammatory disease. Infect Dis Obstet Gynecol [Internet]. 2011 Dec [cited 2020 Oct 2];2011:959816. Available from: https://dx.doi. org $/ 10.1155 \% 2 \mathrm{~F} 2011 \% 2 \mathrm{~F} 959816$

25. Weinstein SA, Stiles BG. A review of the epidemiology, diagnosis and evidence-based management of Mycoplasma genitalium. Sex Health [Internet]. 2011 Jun [cited 2020 Oct 2];8(2):143-58. Available from: https://doi.org/10.1071/sh10065

26. McGowin CL, Anderson-Smits C. Mycoplasma genitalium: an emerging cause of sexually transmitted disease in women. PLoS Pathog [Internet]. 2011 May [cited 2020 Oct 2];7(5):e1001324. Available from: https://dx.doi.org/10.1371\%2Fjournal.ppat.1001324

27. Brunham RC, Gottlieb SL, Paavonen J. Pelvic inflammatory disease. N Engl J Med [Internet]. 2015 May [cited 2020 Oct 2];372(21):2039-48. Available from: https://doi.org/10.1056/NEJMra1411426

28. Zhou X, Bent SJ, Schneider MG, Davis CC, Islan MR, Forney LJ. Characterization of vaginal microbial communities in adult healthy women using cultivation independent methods. Microbiology (Reading) [Internet]. 2004 Aug [cited 2020 Oct 2];150(Pt 8):2565-73. Available from: https://doi.org/10.1099/mic.0.26905-0

29. Galask RP, Larsen B, Ohm MJ. Vaginal flora and its role in disease entities. Clin Obstet Gynecol [Internet]. 1976 Mar [cited 2020 Oct 2];19(1):61-81. Available from: https://doi.org/10.1097/00003081197603000-00008

30. Srinivasan S, Hoffman NG, Morgan MT, Matsen FA, Fiedler TL, Hall $\mathrm{RW}$, et al. Bacterial communities in women with bacterial vaginosis: high resolution phylogenetic analyses reveal relationships of microbiota to clinical criteria. PLoS One [Internet]. 2012 Jun [cited 2020 Oct 2];7(6):e37818. Available from: https://doi.org/10.1371/journal.pone.0037818

31. Moller BR, Kritiansen FV, Thorsen P, Frost L, Mogensen SC. Sterility of the uterine cavity. Acta Obstet Gynecol Scand [Internet]. 1995 Mar [cited 2020 Oct 2];74(3):216-9. Available from: https://doi. org/10.3109/00016349509008942

32. Kyono K, Hashimoto T, Nagai Y, Sakuraba Y. Analysis of endometrial microbiota by $16 \mathrm{~S}$ ribosomal RNA gene sequencing among infertile patients: a single-center pilot study. Reprod Med Biol [Internet]. 2018 Jul [cited 2020 Oct 2];17(3):297-306. Available from: https://dx.doi. org $/ 10.1002 \% 2$ Frmb2.12105

33. Sharma H, Tal R, Clark NA, Segars JH. Microbiota and pelvic inflammatory disease. Semin Reprod Med [Internet]. 2014 Aug [cited 2020 Oct 2];32(1):43-9. Available from: https://dx.doi. org $/ 10.1055 \% 2 \mathrm{Fs}-0033-1361822$

34. Ministério da Saúde (BR). Secretaria de Vigilância em Saúde. Departamento de Doenças de Condições Crônicas e Infecções Sexualmente Transmissíveis. Protocolo clínico e diretrizes terapêuticas para atenção integral às pessoas com infecções sexualmente transmissíveis (IST) [Internet]. Brasília: Ministério da Saúde; 2015 [cited 2020 Oct 2]. Available from: http://www.aids.gov.br/pt-br/ pub/2015/protocolo-clinico-e-diretrizes-terapeuticas-para-atencaointegral-pessoas-com-infeccoes

35. Simms I, Stephenson JM, Mallinson H, Peeling RW, Thomas K, Gokhale $\mathrm{R}$, et al. Risk factors associated with pelvic inflammatory disease. Sex Transm Infect [Internet]. 2006 Dec [cited 2020 Oct 2];82(6):452-7. Available from: https://dx.doi.org/10.1136\%2Fsti.2005.019539

36. Hoenderboom BM, van Benthem BHB, van Bergen JEAM, DukersMuijrers NHTM, Götz HM, Hoebe CJPA, et al. Relation between Chlamydia trachomatis infection and pelvic inflammatory disease, ectopic pregnancy and tubal factor infertility in a Dutch cohort of women previously tested for chlamydia in a chlamydia screening trial. Sex Transm Infect [Internet]. 2019 Jun [cited 2020 Oct 2];95(4):300-6. Available from: https://doi.org/10.1136/sextrans-2018-053778
37. Meirik O. Intrauterine devices - upper and lower genital tract infections Contraception [Internet]. 2007 Jun [cited 2020 Oct 2];75(Suppl 6):S41-7. Available from: https://doi.org/10.1016/j.contraception.2006.12.017

38. Caddy S, Yudin MH, Hakim J, Money DM; Infectious Disease Committee; Special Contributor. Best practices to minimize risk of infection with intrauterine device insertion. J Obstet Gynaecol Can [Internet]. 2014 Mar [cited 2020 Oct 2];36(3):266-74. Available from: https://doi.org/10.1016/s1701-2163(15)30636-8

39. Wiesenfeld HC, Sweet RL, Ness RB, Krohn MA, Amortegui AJ, Hillier SL. Comparison of acute and subclinical pelvic inflammatory disease. Sex Transm Dis [Internet]. 2005 Jul [cited 2020 Oct 2];32(7):400-5. Available from: https://doi.org/10.1097/01.olq.0000154508.26532.6a

40. Jacobson L, Weström L. Objectivized diagnosis of acute pelvic inflammatory disease. Diagnostic and prognostic value of routine laparoscopy. Am J Obstet Gynecol [Internet]. 1969 Dec [cited 2020 Oct 2];105(7):1088-98. Available from: https://doi.org/10.1016/00029378(69)90132-x

41. Ross J, Cole M, Evans C, Deirdre L, Dean G, Cousins D. United Kingdom national guideline for the management of pelvic inflammatory disease (2019 interim update) [Internet]. United Kingdom: British association for sexual health and HIV BASHH; 2019 [cited 2020 Jul 22]. Available from: https://www.bashhguidelines.org/media/1217/pid-update-2019.pdf

42. Workowski KA, Bolan GA; Centers for Disease Control and Prevention. Sexually transmitted diseases treatment guidelines, 2015. MMWR Recomm Rep [Internet]. 2015 Jun [cited 2020 Oct 2];64(RR-03):1-137. Available from: https://www.cdc.gov/mmwr/preview/mmwrhtml/ rr6403a1.htm

43. Ross J, Guaschino S, Cusini M, Jensen J. 2017 European guideline for the management of pelvic inflammatory disease. Int J STD AIDS [Internet]. 2018 Feb [cited 2020 Oct 2];29(2):108-14. Available from: https://doi.org/10.1177/0956462417744099

44. Curry A, Williams T, Penny ML. Pelvic inflammatory disease: diagnosis, management, and prevention. Am Fam Physician [Internet]. 2019 Sep [cited 2020 Oct 2];100(6):357-64. Available from: https:// www.aafp.org/afp/2019/0915/p357.html

45. Weström L, Joesoef R, Reynolds G, Hagdu A, Thompson SE. Pelvic inflammatory disease and fertility. A cohort study of 1,844 women with laparoscopically verified disease and 657 control women with normal laparoscopic results. Sex Transm Dis [Internet]. 1992 Jul-Aug [cited 2020 Oct 2];19(4):185-92. Available from: https://journals.lww.com/ stdjournal/Citation/1992/07000/Pelvic_Inflammatory_Disease_and Fertility_A.1.aspx

46. Lanjouw E, Ouburg S, Vries HJ, Stary A, Radcliffe K, Unemo M. Background review for the '2015 European guideline on the management of Chlamydia trachomatis infections'. Int J STD AIDS [Internet]. 2015 Nov [cited 2020 Oct 2]. Online ahead of print. Available from: https://doi.org/10.1177/0956462415618838

47. Golden MR, Workowski KA, Bolan G. Developing a public health response to Mycoplasma genitalium. J Infect Dis [Internet]. $2017 \mathrm{Jul}$ [cited 2020 Oct 2];216(Suppl 2):420-6. Available from: https://doi. org/10.1093/infdis/jix200

48. Fouks Y, Cohen Y, Tulandi T, Meiri A, Levin I, Almog B, et al. Complicated clinical course and poor reproductive outcomes of women with tubo-ovarian abscess after fertility treatments. J Minim Invasive Gynecol [Internet]. 2019 Jan [cited 2020 Oct 2];26(1):162-8. Available from: https://doi.org/10.1016/j.jmig.2018.06.004

49. Fehring RJ, Bouchard T, Meyers M. Influence of contraception use on the reproductive health of adolescents and young adults. Linacre Q [Internet]. 2018 May [cited 2020 Oct 2];85(2):167-77. Available from: https://doi.org/10.1177/0024363918770462 
50. Haumann A, Ongaro S, Detry O, Meunier P, Meurisse M. Acute pelvic inflammatory disease as a rare cause of acute small bowel obstruction. Acta Chir Belg [Internet]. 2019 Oct [cited 2020 Oct 2];119(5):328-30. Available from: https://doi.org/10.1080/00015458.2018.1453438

51. World Health Organization - WHO. Diagnóstico laboratorial de doenças sexualmente transmissíveis, incluindo o vírus da imunodeficiência humana [Internet]. Brasília: Organização Mundial da Saúde; Ministério da Saúde; 2013 [cited 2020 Jul 22]. 255 p. Available from: https://www. who.int/reproductivehealth/publications/rtis/9789241505840/en/

52. Cicchiello LA, Hamper UM, Scoutt LM. Ultrasound evaluation of gynecologic causes of pelvic pain. Obstet Gynecol Clin North Am [Internet]. 2011 Mar [cited 2020 Oct 2];38(1):85-114, viii. Available from: https://doi.org/10.1016/j.ogc.2011.02.005

53. Papavarnavas CP, Venter PF, van Staden MJ. Acute salpingitis laparoscopic and microbiological evaluation. S Afr Med J. 1990 Apr;77(8):403-4.

54. Hillis SD, Joesoef R, Marchbanks PA, Wasserheit JN, Cates W Jr, Westrom L. Delayed care of pelvic inflammatory disease as a risk factor for impaired fertility. Am J Obstet Gynecol [Internet]. 1993 May [cited 2020 Ocr 2];168(5):1503-9. Available from: https://doi.org/10.1016/s0002-9378(11)90790-x

55. Jaiyeoba O, Lazenby G, Soper DE. Recommendations and rationale for the treatment of pelvic inflammatory disease. Expert Rev Anti Infect Ther [Internet]. 2011 Jan [cited 2020 Oct 2];9(1):61-70. Available from: https://doi.org/10.1586/eri.10.156

56. Duarte R, Fuhrich D, Ross JD. A review of antibiotic therapy for pelvic inflammatory disease. Int J Antimicrob Agents [Internet]. 2015 Sep [cited 2020 Oct 2];46(3):272-7. Available from: https://doi.org/10.1016/j. ijantimicag.2015.05.004

57. Bazzo ML, Golfetto L, Gaspar PC, Pires AF, Ramos MC, Franchini $\mathrm{M}$, et al. First nationwide antimicrobial susceptibility surveillance for Neisseria gonorrhoeae in Brazil, 2015-16. J Antimicrob Chemother [Internet]. 2018 Jul [cited 2020 Oct 2];73(7):1854-61. Available from: https://doi.org/10.1093/jac/dky090

58. Ministério da Saúde (BR). Secretaria de Ciência, Tecnologia e Insumos Estratégicos. Comissão Nacional de Incorporação de Tecnologias no SUS (Conitec). Ceftriaxona 500mg para tratamento da Neisseria gonorrhoeae resistente à ciprofloxacina [Internet]. Brasília: Ministério da Saúde; 2015 [cited 2020 Oct 2]. (Relatório de Recomendação, n. 154). 29 p. Available from: http://conitec.gov.br/images/Relatorios/2015/ Relatorio_Ceftriaxona_Gonorreia final.pdf
59. Mitchell C, Prabhu M. Pelvic inflammatory disease: current concepts in pathogenesis, diagnosis and treatment. Infect Dis Clin North Am [Internet]. 2013 Dec [cited 2020 Oct 2];27(4):793-809. Available from: https://doi.org/10.1016/j.idc.2013.08.004

60. Public Health Agency of Canada - PHAC. Pelvic inflammatory disease (PID). In: PHAC. Updates to the Canadian guidelines on sexually transmitted infections [Internet]. Ottawa: PHAC; 2008 [cited 2020 Jul 22]. 436 p. Available from: https://fhs.mcmaster.ca/medicine/ infectious diseases/residents/docs/Canadian-STI-Guidelines2008.pdf

61. Jennings LK, Krywko DM. Pelvic inflammatory disease (PID). Stat Pearls [Internet]. 2020 Jun [cited $2020 \mathrm{Jul}$ 22]. Available from: https:// www.ncbi.nlm.nih.gov/books/NBK499959/

62. Safrai M, Rottenstreich A, Shushan A, Gilad R, Benshushan A, Levin G. Risk factors for recurrent Pelvic Inflammatory Disease. Eur J Obstet Gynecol Reprod Biol [Internet]. 2020 Jan [cited 2020 Oct 2];244:40-4. Available from: https://doi.org/10.1016/j.ejogrb.2019.11.004

63. Brasil. Ministério da Saúde. Portaria MS/SVS no 33, de 14de julho de 2005. Inclui doenças à relação de notificação compulsória, define agravos de notificação imediata e a relação dos resultados laboratoriais que devem ser notificados pelos Laboratórios de Referência Nacional ou Regional [Internet]. Diário Oficial da União, Brasília (DF), 2005 jul 15 [cited 2020 Oct 2];Seção 1:111. Available from: http://bvsms.saude.gov. br/bvs/saudelegis/svs/2005/prt0033_14_07_2005.html

64. Wiesenfeld HC. Screening for Chlamydia trachomatis infections in women. N Engl J Med [Internet]. 2017 Feb [cited 2020 Oct 2];376(8):76573. Available from: https://doi.org/10.1056/nejmcp1412935

65. Pinto-Sander N, Soni S. Mycoplasma genitalium infection. BMJ [Internet]. 2019 Oct [cited 2020 Oct 2];367:15820. Available from: https://doi.org/10.1136/bmj.15820

66. Greydanus DE, Dodich C. Pelvic inflammatory disease in the adolescent: a poignant, perplexing, potentially preventable problem for patients and physicians. Curr Opin Pediatr [Internet]. 2015 Feb [cited 2020 Oct 2];27(1):92-9. Available from: https://doi.org/10.1097/ mop.0000000000000183

67. Solomon M, Tuchman L, Hayes K, Badolato G, Goyal MK. Pelvic inflammatory disease in a pediatric emergency department: epidemiology and treatment. Pediatr Emerg Care [Internet]. 2019 Jun [cited 2020 Oct 2];35(6):389-90. Available from: https://doi.org/10.1097/ pec. 0000000000001148 